\title{
Sulforaphane increases the efficacy of anti-androgens by rapidly decreasing androgen receptor levels in prostate cancer cells
}

\author{
NAMRATA KHURANA ${ }^{1,3}$, SUDHA TALWAR ${ }^{1}$, PARTHA K. CHANDRA ${ }^{2}$, PANKAJ SHARMA ${ }^{3}$, \\ ASIM B. ABDEL-MAGEED ${ }^{1}$, DEBASIS MONDAL ${ }^{2 *}$ and SURESH C. SIKKA ${ }^{1 *}$ \\ Departments of ${ }^{1}$ Urology and ${ }^{2}$ Pharmacology, Tulane University School of Medicine, New Orleans, LA 70112, USA; \\ ${ }^{3}$ Amity Institute of Biotechnology, Amity University, Noida, U.P. 201313, India
}

Received May 2, 2016; Accepted July 11, 2016

DOI: $10.3892 /$ ijo.2016.3641

\begin{abstract}
Prostate cancer (PCa) cells utilize androgen for their growth. Hence, androgen deprivation therapy (ADT) using antiandrogens, e.g. bicalutamide (BIC) and enzalutamide (ENZ), is a mainstay of treatment. However, the outgrowth of castration resistant $\mathrm{PCa}(\mathrm{CRPC})$ cells remains a significant problem. These CRPC cells express androgen receptor (AR) and utilize the intratumoral androgen towards their continued growth and invasion. Sulforaphane (SFN), a naturally occurring isothiocyanate found in cruciferous vegetables, can decrease AR protein levels. In the present study, we tested the combined efficacy of anti-androgens and SFN in suppressing PCa cell growth, motility and clonogenic ability. Both androgen-dependent (LNCaP) and androgen-independent (C4-2B) cells were used to monitor the effects of BIC and ENZ, alone and in combination with SFN. Co-exposure to SFN significantly $(\mathrm{P}<0.005)$ enhanced the anti-proliferative effects of anti-androgens and downregulated expression of the AR-responsive gene, prostate specific antigen (PSA) $(\mathrm{P}<0.05)$. Exposure to SFN decreased AR protein levels in a time- and dose-dependent manner with almost no AR detected at $24 \mathrm{~h}$ with $15 \mu \mathrm{M} \mathrm{SFN}(\mathrm{P}<0.005)$. This rapid and potent AR suppression by SFN occurred by both AR protein degradation, as suggested by cycloheximide (CHX) co-exposure studies, and by suppression of AR gene expression, as evident from quantitative RT-PCR experiments. Pre-exposure to SFN also reduced R1881-stimulated nuclear
\end{abstract}

Correspondence to: Dr Suresh C. Sikka, Department of Urology, Tulane University Medical Center, 1430 Tulane Avenue, New Orleans, LA 70112, USA

E-mail:ssikka@tulane.edu

Dr Debasis Mondal, Department of Pharmacology, Tulane University Medical Center, 1430 Tulane Avenue, New Orleans, LA 70112, USA

E-mail:dmondal@tulane.edu

*Contributed equally

Key words: prostate cancer, androgen receptor, sulforaphane, bicalutamide, enzalutamide, combination therapy, proliferation, migration, colony formation localization of AR, and combined treatment with SFN and antiandrogens abrogated the mitogenic effects of this AR-agonist $(\mathrm{P}<0.005)$. Wound-healing assays revealed that co-exposure to $\mathrm{SFN}$ and anti-androgens can significantly $(\mathrm{P}<0.005)$ reduce $\mathrm{PCa}$ cell migration. In addition, long-term exposures (14 days) to much lower concentrations of these agents, SFN $(0.2 \mu \mathrm{M})$, BIC $(1 \mu \mathrm{M})$ and/or ENZ $(0.4 \mu \mathrm{M})$ significantly $(\mathrm{P}<0.005)$ decreased the number of colony forming units (CFUs). These findings clearly suggest that SFN may be used as a promising adjunct agent to augment the efficacy of anti-androgens against aggressive PCa cells.

\section{Introduction}

Prostate cancer (PCa) is the second leading cause of cancerrelated deaths in men in the Unites States (1). Androgen receptor (AR) signaling is crucial not only for the normal development and physiological functioning of the prostate gland but is also critical for increased proliferation, survival, invasion and clonogenic ability of the PCa cells $(2,3)$. Therefore, the androgen-induced protein, prostate specific antigen (PSA) is an effective biomarker during the early stages of PCa growth (4).

Androgen deprivation therapy (ADT), achieved via the simultaneous suppression of testicular androgen production by using luteinizing hormone-releasing hormone (LHRH) analogues and inhibition of AR binding with the residual androgens using AR antagonists (anti-androgens) like casodex (bicalutamide; BIC) and MDV3100 (enzalutamide; ENZ) remains a gold standard treatment in PCa patients $(5,6)$. However, despite the initial efficacy of ADT, tumors eventually become resistant to even high doses of AR antagonists and this hormone-refractory or castration resistant prostate cancer (CRPC) is a significant challenge to therapy (7-15). Indeed, these clinically approved drugs are administered as first line anti-hormonal therapy in PCa patients. However, the side-effects associated with chronic high doses of these antiandrogens (16-18) warrant the need to use adjuvant agents that can increase the efficacy of BIC and ENZ, which will significantly reduce their side-effects and augment their clinical effectiveness.

Various mechanisms attributable to this resistance include ligand independent activation of AR by growth factors, 
cytokines or kinases; intracrine or intratumoral androgen production; amplification of AR gene; gain-of-function mutations leading to AR activation by AR antagonists; overexpression of AR coactivators and/or expression of constitutively active AR splice variants (19-21). Thus, decreasing the incessant AR signaling in the androgen dependent PCa cells and hampering the transition of androgen independent PCa cells to aggressive CRPC will be a principal approach towards increased therapeutic efficacy of ADT. Strategies that suppress AR protein levels in $\mathrm{PCa}$ cells and significantly improve the efficacy of clinically approved anti-androgens (e.g. BIC and ENZ) will be of significance in treating patients with CRPC tumors.

Sulforaphane (SFN), an isothiocyanate found in cruciferous vegetables (e.g. broccoli) is a promising therapeutic agent for metastatic PCa since it shows specific cytotoxicity towards transformed cells without having significant adverse effects on primary prostate epithelial cells (22-29). Mechanistic studies have shown that SFN-induced cell death is initiated by the release of reactive oxygen species (ROS) $(30,31)$ and hydrogen sulfide (32); epigenetic modifications of $N r f$-2 leading to the activation of downstream anti-oxidative/detoxification stress pathway and by suppression of the Akt survival pathway (33-35). Mechanistically, SFN has been shown to decrease AR protein levels by inhibiting the transcription of $A R$ gene (36) and increasing the proteasomal degradation of AR protein $(37,38)$. We hypothesized that combined exposure to SFN will enhance the efficacy of anti-androgens that block AR function by competitively inhibiting ligand (androgen) binding. Our studies demonstrate this novel phenomenon at both the cellular and molecular levels. Co-treatment with physiologically achievable levels of SFN synergistically increased the anticancer efficacy of both BIC and ENZ in both androgen dependent LNCaP cells and in its CRPC subline, C4-2B cells.

\section{Materials and methods}

Cell culture. LNCaP, an androgen-dependent (AD) prostate cancer cell line, was purchased from the American Type Culture Collection (ATCC; Rockville, MD, USA). C4-2B cells, a CRPC sub-line of LNCaP, was a kind gift from Dr Leland Chung's laboratory (Emory University, Atlanta, GA, USA) (39). Both cell lines were maintained in RPMI1640 media containing 1\% penicillin/streptomycin (Cellgro, Manassas, VA, USA) supplemented with $10 \%$ fetal bovine serum (FBS; Atlanta Biologicals, Inc., Lawrenceville, GA, USA) in a humidified incubator containing $5 \% \mathrm{CO}_{2}$ at $37^{\circ} \mathrm{C}$. To mimic steroid hormone deprived conditions, experiments were carried out in media supplemented with $10 \%$ charcoalstripped FBS (CS-FBS) from Atlanta Biologicals.

Reagents. Sulforaphane (SFN), bicalutamide (BIC) and MTT (3-(4,5-dimethylthiazol-2-yl)-2,5-diphenyltetrazolium bromide) were obtained from Sigma-Aldrich (St. Louis, MO, USA). Enzalutamide was purchased from Apexbio Technology LLC (Houston, TX, USA). Cycloheximide (CHX) was purchased from Cayman Chemical (Ann Arbor, MI, USA). The synthetic androgen-agonist, R1881 was obtained from Perkin-Elmer (Waltham, MA, USA). All drugs were dissolved in dimethyl sulfoxide (DMSO) and final DMSO concentration used was $<0.1 \%$. The primary antibodies including rabbit polyclonal anti-AR (N-20) (sc-816), goat polyclonal anti-Lamin B (C-20) (sc-6216) and mouse monoclonal anti-GAPDH (sc-47724) were purchased from Santa Cruz Biotechnology (Santa Cruz, CA, USA). The horseradish peroxidase (HRP)conjugated goat anti-rabbit (A0545) and goat anti-mouse (A9044) secondary antibodies were purchased from SigmaAldrich. The goat anti-rabbit secondary antibody tagged with Texas Red (T-2767) was purchased from Thermo Fisher Scientific (Rockford, IL, USA). The quantitative RT-PCR (qRT-PCR) primers were synthesized by Integrated DNA Technologies Inc. (Coralville, IA, USA).

Cell viability assay. MTT assays were performed to determine cell viability post exposure to the $\operatorname{drug}(\mathrm{s})$. In brief, $\sim 5,000$ cells were seeded in 96-well culture plates and allowed to adhere overnight. Cells were then synchronized by overnight incubation in serum-free medium, and then treated with desired concentrations of $\operatorname{drug}(\mathrm{s})$, alone or in different combinations for 24-72 h. Cell viability was determined by adding MTT solution $(5 \mathrm{mg} / \mathrm{ml})$ and incubating for $3 \mathrm{~h}$ at $37^{\circ} \mathrm{C}$. The formazan crystals formed were then solubilized in DMSO and optical density was measured spectrophotometrically at $540 \mathrm{~nm}$ using a $\mu$ Quant plate reader (US BioTek Laboratories, Shoreline, WA, USA). Cell survival is expressed as percent of control.

Western immunoblot. Whole cell lysates were harvested at different time-points post-treatment(s) using RIPA lysis buffer from Santa Cruz Biotechnology and total protein content was quantified using the bicinchoninic acid (BCA) protein assay reagent (Thermo Fisher Scientific). Approximately $10 \mu \mathrm{g}$ of protein was electrophoresed in 10\% SDS-PAGE gels followed by electro-transfer onto nitrocellulose membrane. After blocking in 5\% casein in TBS-T buffer (Tris-buffered saline with $0.1 \%$ Tween-20), membranes were incubated overnight at $4^{\circ} \mathrm{C}$ with the primary antibodies (1:500 dilution) followed by incubation with the corresponding HRP-conjugated secondary antibodies (1:2,000 dilution) for $1 \mathrm{~h}$. Membranes were developed using the SuperSignal West Femto Substrate (Thermo Fisher Scientific). Immunoblots were scanned using ImageQuant LAS 500 (GE Healthcare, Princeton, NJ, USA) and band intensities were quantified using ImageJ software (NIH, Bethesda, MD, USA). Densitometric value for AR protein was normalized to the corresponding GAPDH level in each sample.

Nuclear and cytosolic fractions. Protein from nuclear and cytosolic fractions were isolated using the NE-PER Nuclear and Cytoplasmic Extraction kit (Pierce, Rockford, IL, USA) according to the manufacturer's instructions. Approximately $10 \mu \mathrm{g}$ of both cytoplasmic and nuclear protein was electrophoresed in 10\% SDS-PAGE gels after quantification and resultant immunoblots were analyzed for AR levels as described above (cytosol to nuclei protein contents were 1:6). Densitometric values for AR protein were normalized to either GAPDH (cytoplasmic) or Lamin B (nuclear) levels.

Immunofluorescence microscopy. Subcellular localization of AR post-treatment with SFN in the absence or presence 
of R1881 (1 nM) was visualized by immunofluorescence microscopy (IFM). Briefly, cells $\left(3 \times 10^{4}\right)$ were seeded in chamber slides (EMD Millipore, Billerica, MA, USA) and allowed to adhere overnight. After treatment, cells were fixed in ice cold methanol followed by permeabilization with $0.1 \%$ Triton X-100 for $1 \mathrm{~h}$. After blocking in $10 \%$ goat serum, slides were incubated overnight at $4^{\circ} \mathrm{C}$ with the primary antibody (1:300 dilution) followed by incubation with the corresponding Texas Red tagged secondary antibody (1:1,000 dilution) for $1 \mathrm{~h}$. The Vectashield (Vector Laboratories, Inc., Burlingame, CA, USA) mounting medium containing the nuclear stain diamino-2-phenylindole (DAPI) was then added to the slides and coverslips were mounted. Images were captured using a fluorescent microscope from Leica Microsystems Inc. (Buffalo Grove, IL, USA).

Quantitative RT-PCR. Quantitative reverse transcriptase polymerase chain reaction (qRT-PCR) was carried out to measure the AR gene expression. Briefly, total mRNA was isolated post treatment using the RNeasy Plus Mini kit from Qiagen (Valencia, CA, USA) according to manufacturer's instructions. The complementary DNA (cDNA) was prepared using the iScript cDNA Synthesis kit (Bio-Rad Laboratories) according to the manufacturer's instructions. The following primer sequences were used: AR-forward, 5'-CAGCCTATTGCGAG AGAGCTG-3' and AR-reverse, 5'-GAAAGGATCTTGGGC ACTTGC-3'; $\beta$-actin-forward, 5'-TGAGACCTTCAACACCC CAGCCATG-3' and $\beta$-actin-reverse, 5'-GTAGATGGGCA CAGTGTGGGTG-3'. The relative AR transcript levels were measured using iQ ${ }^{\mathrm{TM}}$ SYBR Green Supermix (Bio-Rad Laboratories) and amplification reactions were carried out using the $\mathrm{C} 1000^{\mathrm{TM}}$ thermal cycler (CFX96; Bio-Rad Laboratories). The following amplification conditions were used: priming at $95^{\circ} \mathrm{C}$ for $5 \mathrm{~min}$, and then 35 cycles of $95^{\circ} \mathrm{C}$ for $30 \mathrm{sec}, 55^{\circ} \mathrm{C}$ for $30 \mathrm{sec}$ and $72^{\circ} \mathrm{C}$ for $30 \mathrm{sec}$. Data ( $\Delta \mathrm{Ct}$ values) were expressed as fold changes in gene expression after normalization to corresponding $\beta$-actin transcript levels.

Wound-healing assay. Wound-healing assays were carried out to measure the migratory phenotype of PCa cells as previously described (40). Briefly, cells were seeded in 6-well plates $\left(1 \times 10^{6}\right.$ cells/well) and grown until they formed a confluent monolayer. The monolayers were scratched using a $200 \mu \mathrm{l}$ pipette tip, wells were washed with phosphate-buffered saline (PBS) and images of the wound (0 time-point) were captured using a Leica Microsystems microscope. Growth media was added back to each culture and treatments were initiated. After appropriate drug treatments for 24-48 h, change in wound images was captured and cell migration (wound closures) was calculated by measuring the distance between 4-5 random points within the wound edges in three replicate wells.

PSA measurement. An ELISA kit (ALPCO Diagnostics, Salem, NH, USA) was used to measure PSA levels in cell culture supernatants using the manufacturer's instructions. Briefly, culture media was collected $48 \mathrm{~h}$ post-treatment with drug(s) and samples were allowed to react with the immobilized anti-PSA antibody on the microtiter wells. Next, a monoclonal anti-PSA antibody conjugated with horseradish peroxidase (HRP) was added and allowed to react with the immobilized
Table $\mathrm{I}_{\text {. }} \mathrm{IC}_{50}$ values for drugs at 24-72 h (MTT assay).

$\mathrm{LNCaP}\left(\mathrm{IC}_{50} \pm \mathrm{SEM}\right)$

\begin{tabular}{lcrc}
\hline Drugs & SFN $(\mu \mathrm{M})$ & BIC $(\mu \mathrm{M})$ & ENZ $(\mu \mathrm{M})$ \\
\hline Time (h) & & & \\
24 & $23.8 \pm 2.33$ & $140 \pm 5.66$ & $62 \pm 2.71$ \\
48 & $22 \pm 2.28$ & $105 \pm 4.62$ & $57 \pm 3.44$ \\
72 & $17.2 \pm 1.3$ & $80 \pm 3.67$ & $49 \pm 2.13$ \\
\hline \multicolumn{4}{c}{ C4-2B $\left(\mathrm{IC}_{50} \pm \mathrm{SEM}\right)$} \\
\hline Drugs & SFN $(\mu \mathrm{M})$ & $\mathrm{BIC}(\mu \mathrm{M})$ & $\mathrm{ENZ}(\mu \mathrm{M})$ \\
\hline Time (h) & & & \\
24 & $26 \pm 3.12$ & $151 \pm 6.32$ & $65 \pm 3.08$ \\
48 & $24 \pm 2.81$ & $107 \pm 5.89$ & $61 \pm 4.23$ \\
72 & $19 \pm 1.6$ & $87 \pm 4.12$ & $53 \pm 5.21$ \\
\hline
\end{tabular}

antigen followed by incubation with the HRP substrate. The optical density (OD) values measured spectrophotometrically at $450 \mathrm{~nm}$ were converted into $\mathrm{ng} / \mathrm{ml}$ of PSA by using a standard curve, and concentrations were normalized with protein content in each sample.

Colony forming unit assay. Cells (500 cells/dish) were seeded in $60-\mathrm{mm}$ petri dishes in 3 replicates and grown in medium supplemented with $2 \%$ FBS. The drugs, alone or in combination, were added after $48 \mathrm{~h}$ and replenished in the second week. After two weeks in culture, colonies were fixed with $100 \%$ ethanol and stained with $0.2 \%$ crystal violet in $20 \%$ methanol. The colony forming units (CFU) were enumerated and grouped according to their sizes, as small, medium and large CFUs by using the ImageJ software (NIH). Changes in CFU number and size were compared in control and drugexposed cultures.

Statistical analysis. Statistical analysis was carried out using the GraphPad Prism Software version 6 (GraphPad Software Inc., San Diego, CA, USA). Results are expressed as the mean \pm standard error of the mean (SEM). Significant changes from controls were determined by a two-tailed Student's t-test and P-values of $<0.05$ were considered significant. For synergy determination, the CompuSyn software (ComboSyn, Inc., Paramus, NJ, USA) was used and combination index (CI) was calculated based on the Chou-Talalay method which quantitatively determines additive $(\mathrm{CI}=1)$, synergistic $(\mathrm{CI}<1)$ or antagonistic (CI >1) effects (41).

\section{Results}

Exposure to SFN rapidly decreases AR protein levels in both LNCAP and C4-2B cells. Dose-dependent cytotoxicity for $\mathrm{SFN}$ at 24-72 h of exposure was first conducted to determine the inhibitory concentration $50\left(\mathrm{IC}_{50}\right)$ values in both $\mathrm{LNCaP}$ and C4-2B cells (Table I). Subsequent studies were carried out using SFN concentrations below its $\operatorname{IC}_{50}(<20 \mu \mathrm{M})$. Immunoblot analysis revealed that SFN causes both time- and 
A

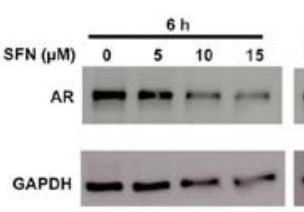

C

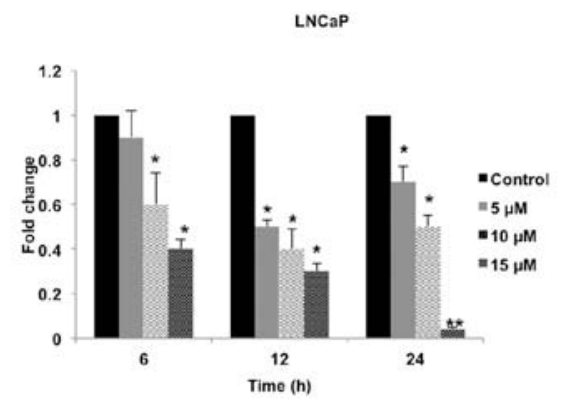

B
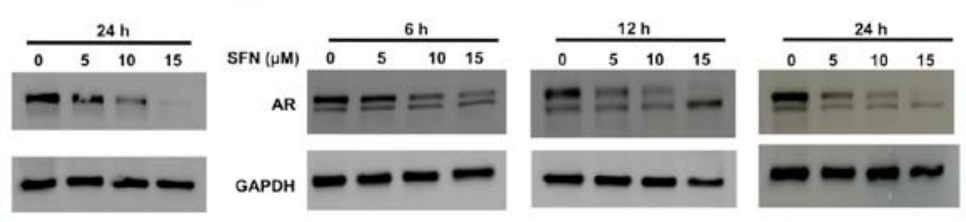

D

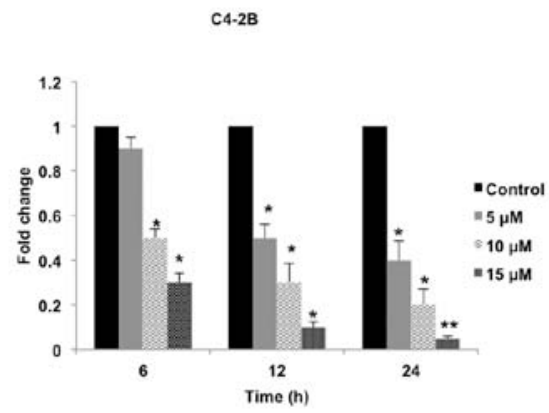

Figure 1. Temporal effects of SFN on AR protein levels in PCa cells. Both LNCaP and C4-2B cells were treated with increasing concentrations of SFN $(0-15 \mu \mathrm{M})$ and cell lysates were obtained at 6-24 h post-treatment. A representative immunoblot of AR and GAPDH protein levels are shown for (A) LNCaP and (B) C4-2B cells. The normalized fold change data are expressed as the mean \pm SEM of three independent experiments in both (C) LNCaP and (D) C4-2B cells. Significant differences between groups are shown as ${ }^{*} \mathrm{P}<0.05 ;{ }^{* *} \mathrm{P}<0.005$.

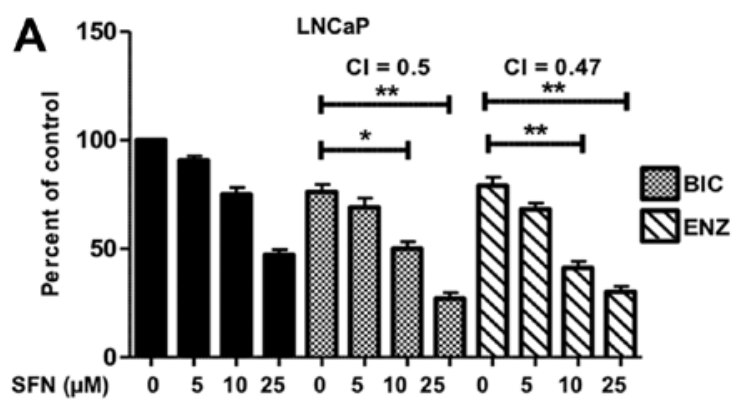

B C4-2B

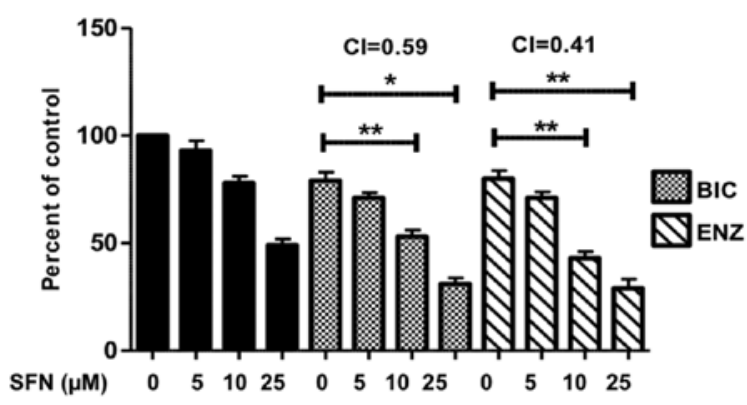

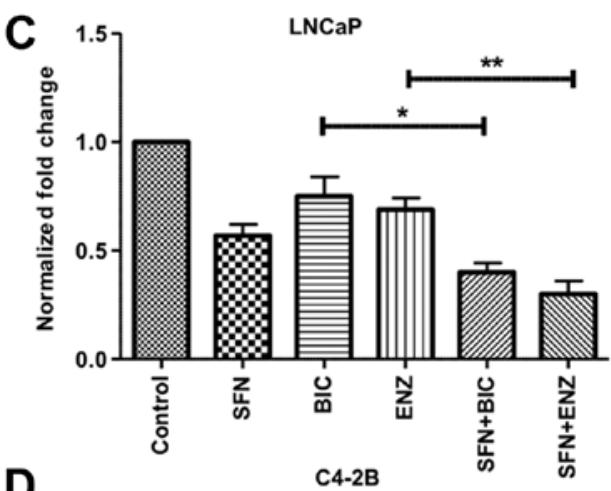

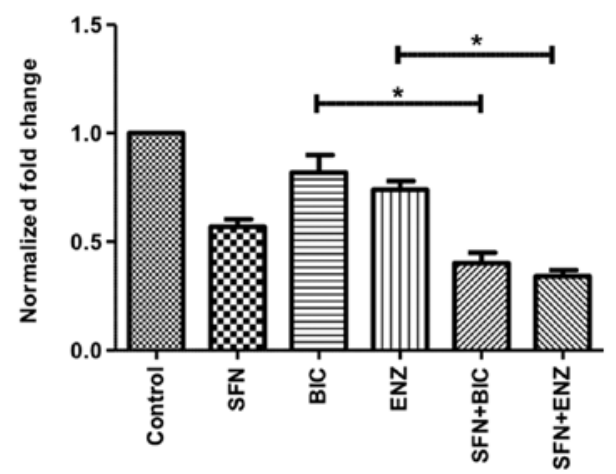

Figure 2. Combined effect of SFN and anti-androgens on cell viability and PSA expression. Cytotoxic effects of BIC (50 $\mu \mathrm{M})$ or ENZ (20 $\mu \mathrm{M})$, alone and in combination with SFN $(5,10$ and $25 \mu \mathrm{M})$ at $48 \mathrm{~h}$ in (A) LNCaP (B) C4-2B cells. The data (\% of control) are expressed as the mean \pm SEM of three independent experiments $(\mathrm{n}=3)$ and significant differences between groups are shown as $\mathrm{P}$-values $\left({ }^{*} \mathrm{P}<0.05 ;{ }^{* *} \mathrm{P}<0.005\right)$. (C and $\left.\mathrm{D}\right)$ The combined effects of SFN $(10 \mu \mathrm{M})$ alone and in combination with BIC $(50 \mu \mathrm{M})$ or ENZ $(20 \mu \mathrm{M})$ on PSA protein levels in culture supernatants at $48 \mathrm{~h}$ is shown in (C) LNCaP and (D) C4-2B cells. The normalized data are expressed as the mean \pm SEM of two independent experiments and significant differences between groups are shown as ${ }^{*} \mathrm{P}<0.05 ;{ }^{* *} \mathrm{P}<0.005$.

dose-dependent decrease of AR protein $(110 \mathrm{kDa})$ in both LNCaP (Fig. 1A and C) and C4-2B (Fig. 1B and D) cells. This suppressive effect was more pronounced in the latter cell line. Decrease in AR protein was apparent within $6 \mathrm{~h}$ post-exposure and even with the lowest concentration of SFN used $(5 \mu \mathrm{M})$ and the AR band was virtually undetectable following $24 \mathrm{~h}$ exposure to $15 \mu \mathrm{M}$ SFN. It is worth noting that we consistently detected a lower molecular weight AR band $(\sim 100 \mathrm{kDa})$ in the C4-2B cells, but not in LNCaP cells. Notably, SFN did not suppress the level of this putative AR variant. 

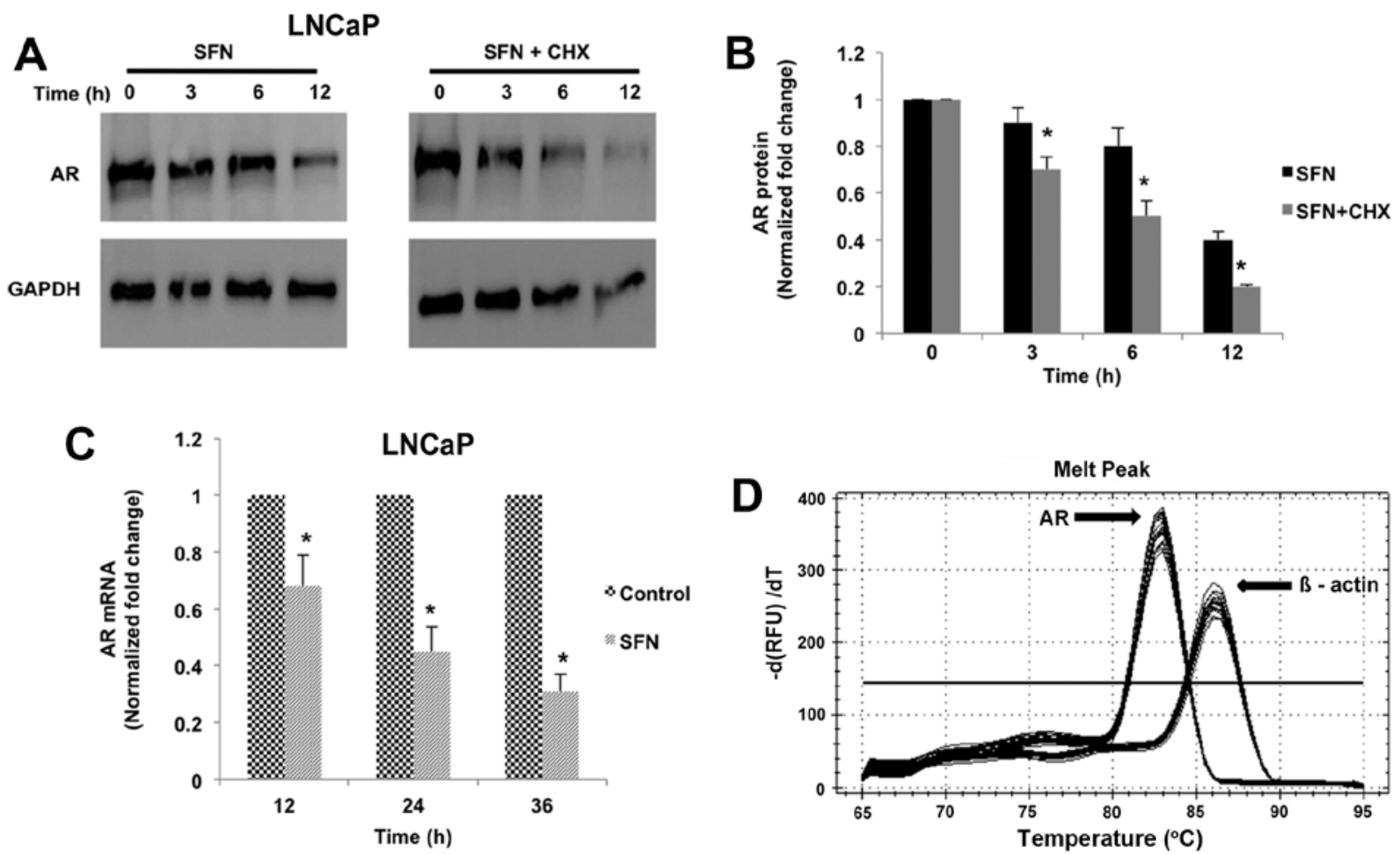

Figure 3. Transcriptional and post-translational regulation of AR by SFN. (A) LNCaP cells were pre-incubated (2 h) with $10 \mu \mathrm{g} / \mathrm{ml}$ cycloheximide (CHX) followed by exposure to SFN $(10 \mu \mathrm{M})$ for 0-12 $\mathrm{h}$ and AR levels were monitored by western immunoblot. (A) A representative immunoblot of AR and GAPDH protein levels in LNCaP cells. (B) The normalized data are expressed as the fold change (mean \pm SEM) of two independent experiments and significant differences between groups are shown as "P<0.05. (C) LNCaP cells were exposed to SFN $(10 \mu \mathrm{M})$ for 12, 24 and $36 \mathrm{~h}$, total RNA extracted and real-time RT-PCR (qRT-PCR) analysis was performed. Normalized fold change in AR gene expression from two independent experiments are expressed as the mean \pm SEM. Significant differences between groups are shown as ${ }^{*} \mathrm{P}<0.05$. (D) The single peaks obtained for AR and $\beta$-actin amplicons during the melting curve analysis verified a single specific PCR product for each gene.

Co-exposure to SFN increases the suppressive effects of antiandrogens on proliferation and PSA expression. As expected, exposure of both $\mathrm{LNCaP}$ and $\mathrm{C} 4-2 \mathrm{~B}$ cells to the anti-androgens for 24-72 $\mathrm{h}$ showed lower $\mathrm{IC}_{50}$ values for the more potent agent, ENZ (Table I). To assess possible synergistic effects in combination with SFN, subsequent studies utilized the sub-IC I0 $_{50}$ values of BIC $(50 \mu \mathrm{M})$ and ENZ $(20 \mu \mathrm{M})$. The highest level of synergy was observed after $48 \mathrm{~h}$ of treatment and the data are presented in the bar graphs (Fig. 2). More than 50\% decrease in viability was observed in both LNCaP (Fig. 2A) and C4-2B (Fig. 2B) cells when SFN (10-25 $\mu \mathrm{M})$ was used in combination with BIC or ENZ. The combination index (CI) values suggested synergistic increase in cytotoxicity in both LNCaP and C4-2B cells. Similarly, SFN co-exposure significantly enhanced the efficacy of BIC or ENZ in reducing the secretory levels of PSA in both LNCaP (Fig. 2C) and C4-2B (Fig. 2D) cells.

SFN-mediated AR suppression is regulated at both posttranslational and transcriptional levels. Immunoblot analysis in LNCaP cells showed that SFN reduced AR protein levels in a time-dependent manner (3, 6 and 12 h); however, pretreatment with the protein-synthesis inhibitor, CHX did not significantly alter this reduction (Fig. $3 \mathrm{~A}$ and $\mathrm{B}$ ). This suggested that SFN regulates AR at the post-translational level, possibly via promoting AR protein degradation. Notably, qRT-PCR analysis showed that continued SFN treatment (12, 24 and $36 \mathrm{~h}$ ) also suppressed AR gene expression in LNCaP cells (Fig. 3C and D). Taken together, these results suggest that the potent AR suppressive effects of SFN may be manifested via its actions on both pre- and post-translational mechanisms of $\mathrm{AR}$ regulation.

SFN suppresses R1881-induced nuclear AR translocation and cell growth. Since AR is a transcription factor and localizes to the nucleus following ligand (androgen) binding (2), we monitored the effect of SFN on both basal AR levels and androgen-induced nuclear AR translocation (Fig. 4A-C). We also monitored the effect of SFN on androgen-induced cell proliferation in PCa cells (Fig. 4D and E). Consistent with SFN-mediated reduction in total AR protein levels (Fig. 1), immunofluorescence studies revealed that $6 \mathrm{~h}$ of pre-exposure to SFN $(10 \mu \mathrm{M})$ decreased both basal as well as R1881-induced AR levels in both cytoplasm and nuclei of $\mathrm{LNCaP}$ and $\mathrm{C} 4-2 \mathrm{~B}$ cells (Fig. 4A and B). These observations were confirmed by immunoblotting studies to document AR levels in cytoplasmic and nuclear fractions of LNCaP cells (Fig. 4C). In LNCaP cells (Fig. 4D) long-term exposure to R1881 increased cell growth by $>2$-fold, and to a lesser extent in the C4-2B cells (Fig. 4E). This growth stimulatory effect of R1881 was partially inhibited by treatment with SFN or BIC alone, and was significantly abrogated with combined exposure to SFN and BIC, as evident in both $\mathrm{LNCaP}$ and $\mathrm{C} 4-2 \mathrm{~B}$ cells (Fig. 4D and E).

SFN enhances the ability of anti-androgens to suppress $P C a$ cell migration. We carried out wound-healing assays to 

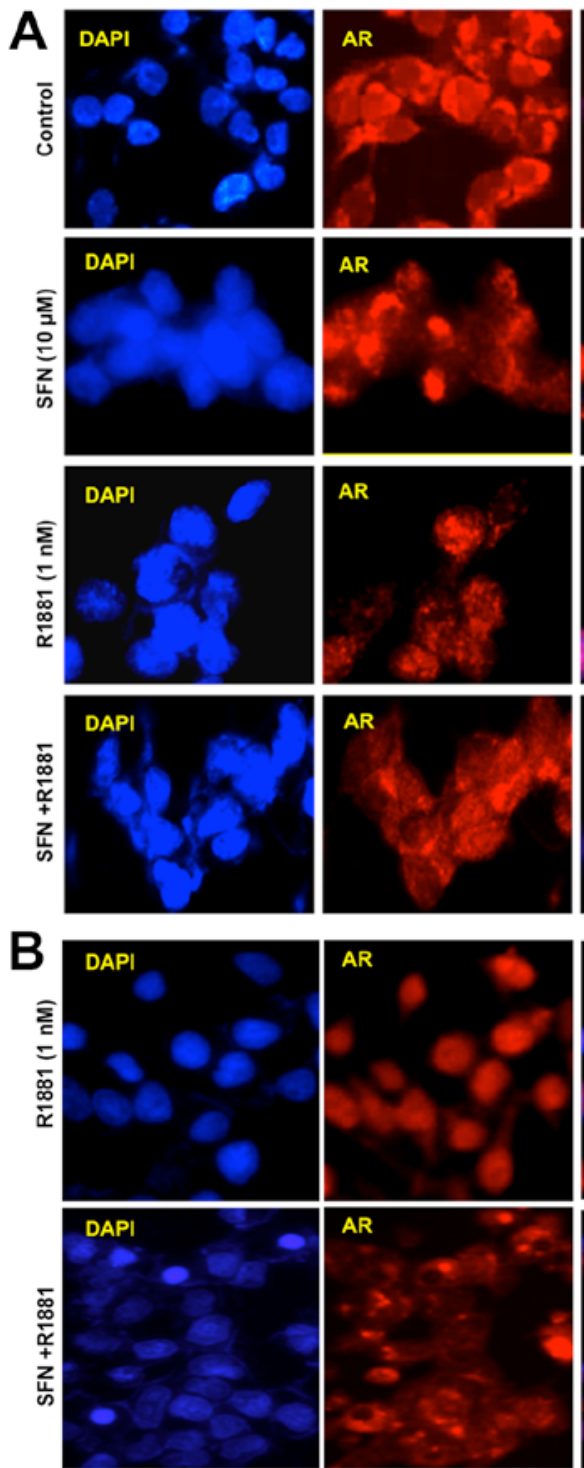
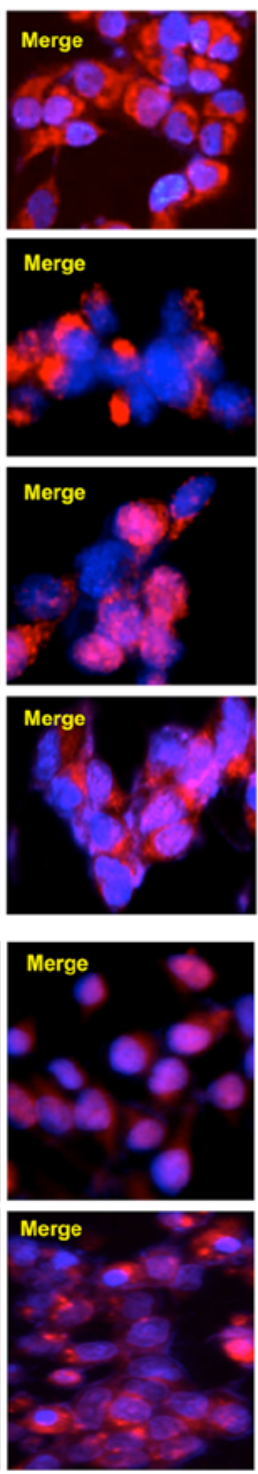

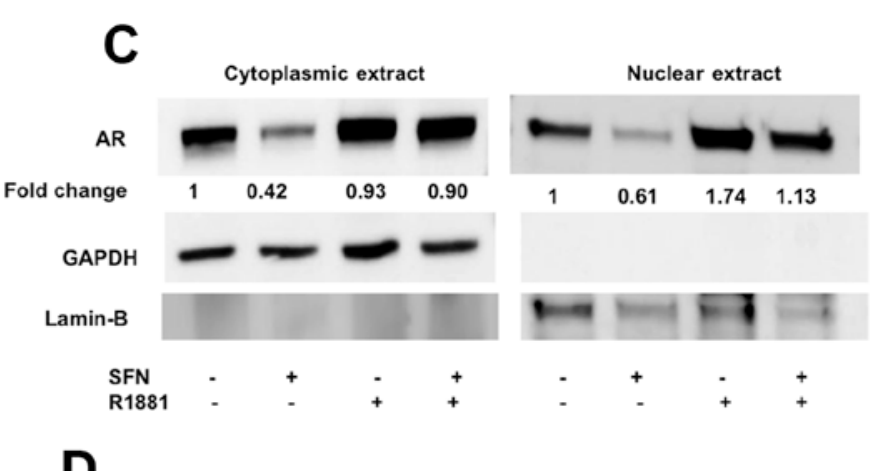

D

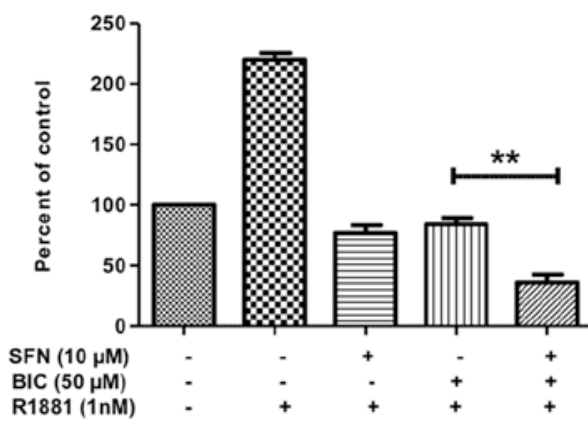

E

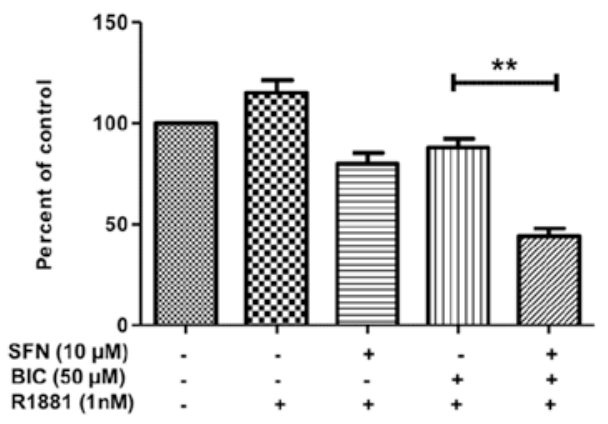

Figure 4. Effect of SFN on R1881-induced nuclear AR and PCa cell growth. Immunofluorescence microscopy (IFM) of subcellular AR localization in (A) LNCaP and (B) C4-2B cells. Cells were treated with SFN $(10 \mu \mathrm{M})$ for $6 \mathrm{~h}$, and in specified samples, cells were stimulated with R1881 (1 nM) during the last $1 \mathrm{~h}$ prior to fixation and immunolabeling. Left panels show DAPI stained nuclei (blue), middle panel shows AR immunoreactivity and merged images are shown in the third panel. (C) Western blot analysis of cytoplasmic and nuclear AR levels in LNCaP cells. Treatments were similar to the IFM studies, but R1881 treatment was followed by cell harvest and subcellular fractionation. Densitometric values for AR protein were normalized to either GAPDH (cytoplasmic) or Lamin B (nuclear) levels. Bar graphs in (D and E) show the growth suppressive effects of SFN $(10 \mu \mathrm{M})$, alone and in combination with BIC (50 $\mu \mathrm{M})$, on R1881 $(1 \mathrm{nM})$ stimulated growth $(48 \mathrm{~h})$ in both LNCaP (D) and C4-2B (E) cells. Data are expressed as the mean \pm SEM of three independent experiments $(\mathrm{n}=3)$ and significant differences between groups are shown as ${ }^{* *} \mathrm{P}<0.005$.

monitor the effect of SFN, alone and/or in combination with anti-androgens (BIC/ENZ) on cell migration behavior (Fig. 5). In control cells, the wound-width decreased by $\sim 50 \%$ after $48 \mathrm{~h}$ in culture, indicating robust cell migration under normal conditions. Exposure to BIC or ENZ alone showed little effect in decreasing cell migration in LNCaP cells (Fig. 5B). However, exposure to even SFN alone enabled $<50 \%$ wound closure and combined exposure to SFN+BIC or SFN+ENZ showed as little as $10-15 \%$ wound closure. Interestingly, this suppressive effect of SFN on migratory behavior of $\mathrm{PCa}$ was more pronounced in the C4-2B cells (Fig. 5A and C). Although, BIC or ENZ alone showed only slight decrease in migratory behavior, exposure to SFN alone decreased migration to $<10 \%$ and combined treatment with SFN and anti-androgens completely suppressed cell migration. In fact, as compared to the initial time-point of wounding, very little wound-healing was evident at $48 \mathrm{~h}$ in the combined drug treatment groups. These experiments demonstrated the efficacy of SFN in suppressing the migratory phenotype of antiandrogen treated PCa cells.

SFN enhances the ability of anti-androgens to suppress clonogenic ability of PCa cells. To examine the long-term (14 days) effects of $\operatorname{drug}(\mathrm{s}), \mathrm{IC}_{50}$ values for SFN, BIC and ENZ on colony-forming ability for $\mathrm{LNCaP}$ and $\mathrm{C} 4-2 \mathrm{~B}$ cells was determined (Table II); the doses that caused $<50 \%$ decrease in CFUs were used for combination studies. SFN exposure caused $\sim 40-45 \%$ decrease in the total number of CFUs in $\mathrm{PCa}$ cells, which were higher than that observed with BIC or ENZ alone. Both SFN+BIC and SFN+ENZ combinations showed significantly striking effect in suppressing the total number of 

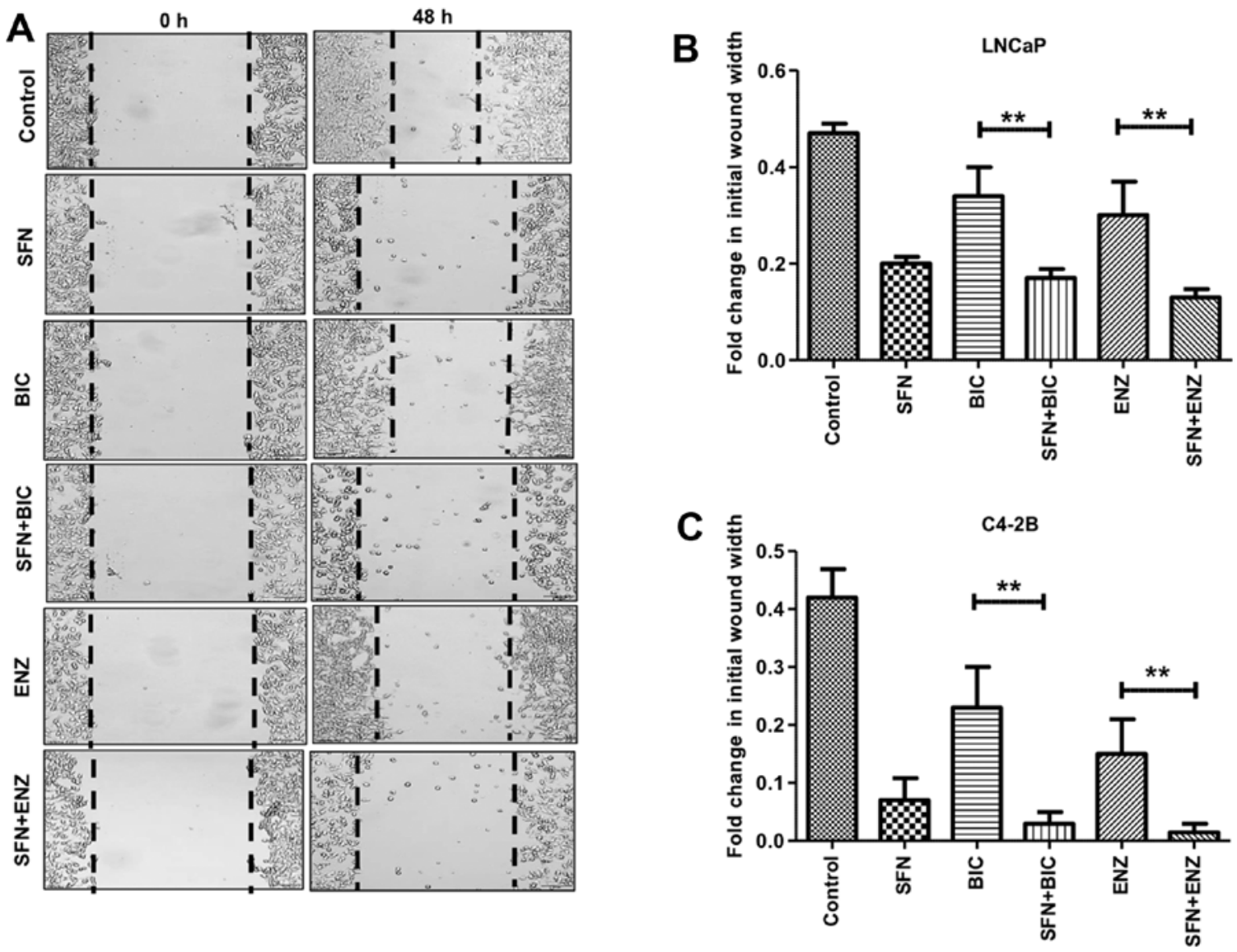

Figure 5. Combined effect of SFN and anti-androgens on PCa cell migration. Quantification of cell migration was examined by wound-healing assays. (A) A representative light microscope image of the wound at the 0 and $48 \mathrm{~h}$ time-points are shown in C4-2B cells, in both control and after treatment with SFN $(10 \mu \mathrm{M}), \mathrm{BIC}(50 \mu \mathrm{M}), \mathrm{ENZ}(20 \mu \mathrm{M})$, alone and/or in combination. The bar graph data are expressed as the mean \pm SEM of two independent experiments and significant differences between groups are shown as ${ }^{* *} \mathrm{P}<0.005$ in both (B) $\mathrm{LNCaP}$ and (C) $\mathrm{C} 4-2 \mathrm{~B}$ cells.

Table II. $\mathrm{IC}_{50}$ values for drugs at 14 days (CFU assay).

\begin{tabular}{|c|c|c|}
\hline & $\mathrm{LNCaP}$ & C4-2B \\
\hline Drugs & $\mathrm{IC}_{50} \pm \mathrm{SEM}$ & $\mathrm{IC}_{50} \pm \mathrm{SEM}$ \\
\hline SFN $(\mu \mathrm{M})$ & $0.3 \pm 0.01$ & $0.38 \pm 0.02$ \\
\hline $\mathrm{BIC}(\mu \mathrm{M})$ & $2 \pm 0.12$ & $2.4 \pm 0.2$ \\
\hline $\operatorname{ENZ}(\mu \mathrm{M})$ & $0.55 \pm 0.029$ & $0.6 \pm 0.035$ \\
\hline
\end{tabular}

CFUs in both LNCaP (Fig. 6A and B) and C4-2B (Fig. 6D and E) cells, as compared to anti-androgens alone. Notably, the inhibitory effect of SFN (either alone or in combination with BIC/ENZ) was more pronounced for large size CFUs as compared to small and medium size CFUs in both LNCaP (Fig. 6C) and C4-2B cells (Fig. 6F). These results suggest that co-exposure to SFN can augment the efficacy of anti-androgens to suppress the clonogenic ability of aggressive PCa cells.

\section{Discussion}

Following anti-androgen therapy, the more aggressive $\mathrm{PCa}$ cells select for the resistant CRPC phenotype. A continuous AR signaling is considered to be a key factor in this inevitable transition (2,3,5-7). A better ablation of AR signaling will enhance the initial anticancer efficacy of clinically approved anti-androgens and thus, delay the outgrowth of CRPC. Although a number of studies have previously shown the anticancer effects of SFN in PCa cells (26,27,30-33), this study is the first to demonstrate the utility of SFN in combination with anti-androgens like BIC and ENZ. In the present in vitro investigations, we show that a rapid, substantial and synergistic sensitization of both androgen-dependent (LNCaP) as well as androgen-independent (C4-2B) PCa cells can be accomplished when SFN is used in combination with anti-androgens. This sensitizing ability of SFN functions via the suppression of AR levels, and decreasing effects of androgen signaling on growth, migration and clonogenic ability.

Previous studies have shown that SFN can suppress AR protein levels in different PCa cell lines (36-38). This study further supported a concentration- and time-dependent effect of sub-toxic SFN doses on AR in both $\mathrm{LNCaP}$ and C4-2B cells (Fig. 1). LNCaP is an androgen-dependent cell line expressing both AR and PSA mRNA/protein which was first isolated from a human metastatic prostate adenocarcinoma in the lymph node $(42,43)$. C4-2B is AR/PSA expressing bone metastatic CRPC subline derived from $\operatorname{LNCaP}(39,43)$. Although these cells can grow in androgen depleted conditions, they need AR both for cell growth and for PSA expression (44). They have also been shown to grow persistently both in 


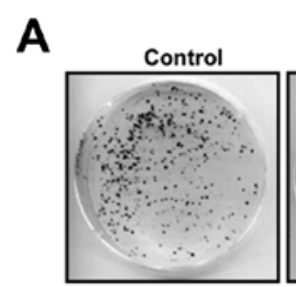

LNCaP

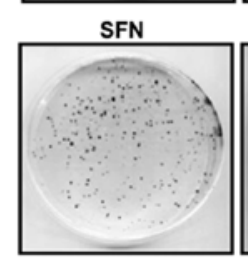

B
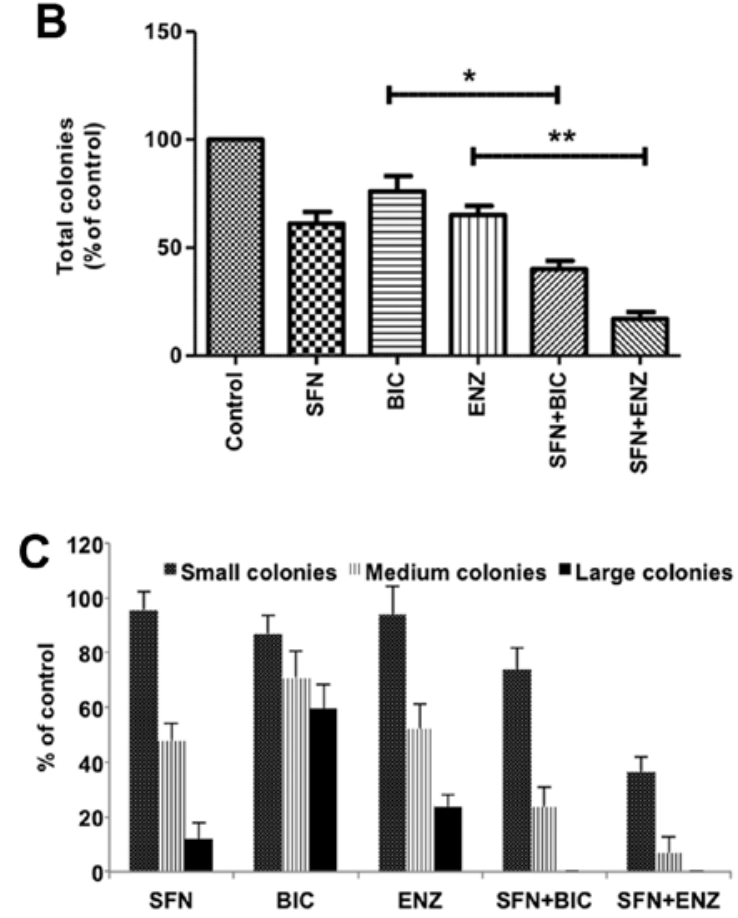

D

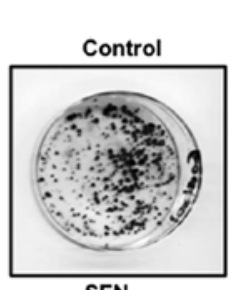

SFN

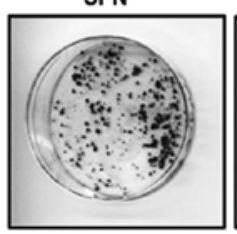

SFN+BIC

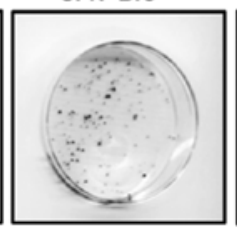

SFN+ENZ

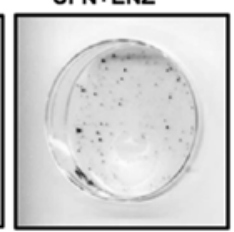

$\mathbf{E}$
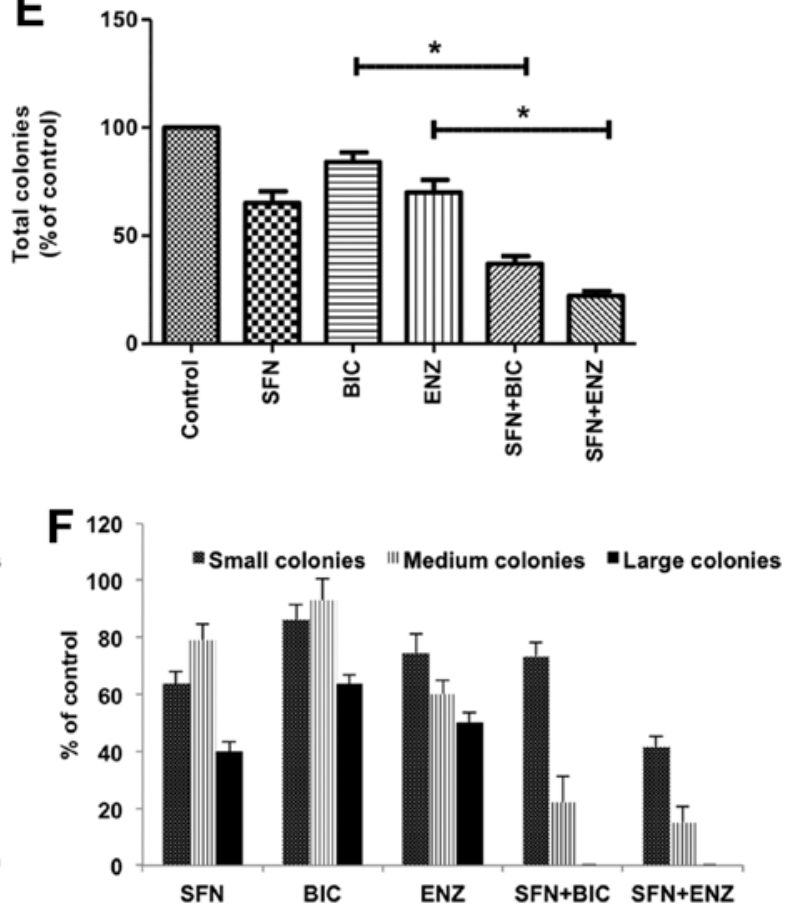

Figure 6. Long-term effects of SFN and anti-androgens on clonogenic ability of PCa cells. Cells (500/plate) were exposed to SFN (0.2 $\mu \mathrm{M})$, alone or in combination with BIC $(1 \mu \mathrm{M})$ and ENZ $(0.4 \mu \mathrm{M})$ for 2 weeks. A representative image of colony forming units (CFU) in LNCaP (A) and C4-2B (D) are shown. As compared to controls, effects of drug exposure on percent change in both total number of CFUs and different size (small, medium and large) CFUs are shown in LNCaP (B and C) and C4-2B (E and F) cells. Data are expressed as the mean \pm SEM of two independent experiments and significant differences between groups are shown as $\mathrm{P}$-values $\left({ }^{*} \mathrm{P}<0.05 ;{ }^{* *} \mathrm{P}<0.005\right)$.

intact as well as castrated mice (43). Thus, C4-2B cells are androgen- independent, but AR dependent similar to LNCaP cells. AR has been reported to remain fully functional in hormone refractory PCa. Ligand-independent activation of AR by cytokines/growth factors, intratumoral/intracrine androgen production and overexpression of AR are mainly responsible for the survival of androgen-independent cells even in the castrate concentrations of androgens (19-21,44). Thus, SFN acts in a similar fashion to degrade AR through the most recognized proteasomal pathway in both androgendependent LNCaP and androgen-independent C4-2B cells. Interestingly, we observed that the downregulation of $\mathrm{AR}$ protein is more pronounced in the $\mathrm{C} 4-2 \mathrm{~B}$ cells, as compared to $\mathrm{LNCaP}$ cells. We established that sub-IC $\mathrm{IC}_{50}$ doses of SFN can rapidly suppress AR in both cell lines and these concentrations of SFN significantly decreased the $\mathrm{IC}_{50}$ of both anti-androgens (Fig. 2A and B).
A number of earlier studies have also shown multimodal actions of SFN in suppressing AR levels in PCa cells (36-38). AR protein is protected from proteasomal degradation via the multi-chaperone complex of heat shock proteins (HSPs) (45). Indeed, HSP-90 inhibitors are known to target AR for proteasomal degradation (46). Previous studies have shown that SFN inhibits HDAC-6. This leads to the hyperacetylation and inactivation of HSP-90 that is responsible for suppressing AR levels $(38,47)$. Androgen binding to AR also dissociates AR from HSP-90 and enables its nuclear translocation $(45,46)$.

ADT increases oxidative stress and proteasomal inhibition, which increases AR stability (48). Antioxidants such as SFN can suppress this effect by increasing $N r f-2(27,33,35)$. Previous studies from our laboratory have shown that $\mathrm{Nrf}-2$ downregulates AR transactivation (34). Our current observations further support the conclusions that SFN co-exposure with BIC and ENZ in both androgen-dependent as well as 
androgen-independent cells leads to: i) significant increase in the anti-proliferative effects (MTT assay); ii) decrease in the secreted levels of AR-regulated gene product PSA (ELISA); iii) decrease in the colony number and size (CFU assay); iv) decrease in the migration ability (wound healing assay); and (v) decrease in the stimulatory growth effects of synthetic AR agonist (R1881) compared to anti-androgens (BIC and ENZ) alone.

The PSA gene is a well-established target of AR signaling, and secreted levels of PSA is often used as a biomarker of PCa growth (4). Anti-androgens, both BIC and ENZ, are known to suppress serum PSA levels (49) but their efficacy in combination with SFN has not been tested before. In the present study, we reported a significant suppression in the secretory levels of PSA in the conditioned media of both $\mathrm{LNCaP}$ and $\mathrm{C} 4-2 \mathrm{~B}$ cells after combined exposure to SFN and anti-androgens (Fig. 2C and D). Thus, our findings corroborate that SFN potentiates the efficiency of clinically approved anti-androgens by decreasing AR protein levels and the transactivation function of AR.

We observed that the rapid effects of SFN in suppressing AR is primarily regulated at the post-translational level. Previous studies have shown that SFN enhances AR protein degradation $(37,38)$ and AR gene expression (36). In this study, pre-treatment with the protein synthesis inhibitor, CHX could not rescue the decrease in AR protein by SFN, suggesting regulation at the post-translation level (Fig. 3A and $\mathrm{B}$ ). Investigations on the effect of SFN on AR mRNA levels suggested that long-term exposure to SFN can result in the downregulation of AR gene expression as well (Fig. 3C). This may be highly beneficial towards the potent therapeutic effects of SFN towards long-term abrogation of all AR-mediated effects on proliferation, invasion and clonogenic ability of aggressive PCa cells. Past studies have indeed demonstrated that AR signaling can regulate its own gene expression (50). Therefore, this dual effect would potentiate the sensitizing ability of SFN when combined with anti-androgens.

The potent AR level suppression by SFN will be of significant advantage in the targeting of CRPC tumors, especially since low levels of androgen have been reported within tumor microenvironments even after castration. This has been attributed to the intratumoral production of androgens by $\mathrm{PCa}$ cells via its de novo biosynthesis from cholesterol and other precursors (8). Residual androgens are sufficient to activate AR signaling, stimulate $\mathrm{PCa}$ growth, and play a crucial role in the progression towards CRPC tumors $(51,52)$. Thus, the continuous nuclear localization of $\mathrm{AR}$ and transcription of $\mathrm{AR}$ regulated genes remains a significant problem despite systemic ADT. We observed that SFN exposure could inhibit the nuclear translocation of AR even in the presence of the synthetic AR agonist, R1881 (Fig. 4A and B). This AR sequestration in the cytosol by SFN was corroborated by both immunofluorescence microscopy and immunoblot analysis of nuclear/cytoplasmic fractions (Fig. 4C). Numerous studies have shown that the continuous AR signaling activates mitogenic pathways in PCa cells (2,3). Therefore, its effective blockade should enable suppression of androgen-stimulated PCa growth. Our investigations showed that SFN co-exposure significantly augmented the anti-proliferative effects of BIC, in both LNCaP (Fig. 4D) and C4-2B cells (Fig. 4E) which were stimulated with R1881. These findings underscore the importance of using SFN as an adjunct agent to suppress the effects of intratumoral androgens in CRPC tumors.

Androgen signaling has also been shown to increase the migratory behavior of PCa cells (2-4). The characteristics of migration include higher invasive ability of cells, elevated apoptotic resistance and increased epithelial mesenchymal transition (EMT) phenotype, crucial determinants of tumor metastasis $(40,53)$. Interestingly, despite their potent antiproliferative effects, anti-androgens have not shown significant effects towards suppressing PCa cell migration (49). The present study clearly shows that SFN co-treatment can impair the migratory ability of both $\mathrm{LNCaP}$ and $\mathrm{C} 4-2 \mathrm{~B}$ cells, and this effect is potentiated in the presence of anti-androgens (Fig. 5). In tumor xenograft models, SFN has been reported to inhibit PCa progression and pulmonary metastasis in vivo (54). Our in vitro finding further suggests the advantage of using SFN in combination with anti-androgens to decrease the metastatic behavior of PCa.

The acute cytotoxic effects observed with this drug combination were further corroborated by chronic exposure in the CFU assays (Fig. 6). These in vitro clonogenic assays mimic the seeding and proliferation of tumor initiating cells (cancer stem cells) and the number of colonies formed post-drug exposure is proportional to the number of viable progenitors (55). The suppressive effect of SFN on tumor initiating cells was reported earlier (56). This study further demonstrated that SFN can potentiate the chronic long-term efficacy of anti-androgens in suppressing the clonogenic potential of both LNCaP and C4-2B cells. Although we did not investigate the efficiency of this combination in vivo, the long-term synergistic effects apparent in our CFU assays, especially with much lower concentrations of each of the agents, clearly implicate the potential of combination therapy in suppressing the seeding and outgrowth of metastatic tumors. Our findings suggest that adjunct therapy with SFN will be highly beneficial in increasing the effectiveness of ADT, both at the initiation of therapy in androgen-dependent PCa cells and during the later stages when PCa cells are selecting for the androgen-independent phenotype. Chronic exposure to this safe phytochemical may impede the progression to CRPC.

\section{Acknowledgements}

The present study was supported by funds from the Louisiana Cancer Research Consortium (LCRC) and the Department of Defense (DoD, \#PC0810811) to D.M. and from the Laboratory Training funds to S.C.S.

\section{References}

1. Yap TA, Zivi A, Omlin A and de Bono JS: The changing therapeutic landscape of castration-resistant prostate cancer. Nat Rev Clin Oncol 8: 597-610, 2011.

2. Hodgson MC, Bowden WA and Agoulnik IU: Androgen receptor footprint on the way to prostate cancer progression. World J Urol 30: 279-285, 2012.

3. Chang KH, Ercole CE and Sharifi N: Androgen metabolism in prostate cancer: From molecular mechanisms to clinical consequences. Br J Cancer 111: 1249-1254, 2014. 
4. Ryan CJ, Smith A, Lal P, Satagopan J, Reuter V, Scardino P, Gerald W and Scher HI: Persistent prostate-specific antigen expression after neoadjuvant androgen depletion: An early predictor of relapse or incomplete androgen suppression. Urology 68: 834-839, 2006

5. Harris WP, Mostaghel EA, Nelson PS and Montgomery B: Androgen deprivation therapy: Progress in understanding mechanisms of resistance and optimizing androgen depletion. Nat Clin Pract Urol 6: 76-85, 2009.

6. Godbole AM and Njar VC: New insights into the androgentargeted therapies and epigenetic therapies in prostate cancer Prostate Cancer 2011: 918707, 2011.

7. Kim W and Ryan CJ: Androgen receptor directed therapies in castration-resistant metastatic prostate cancer. Curr Treat Options Oncol 13: 189-200, 2012.

8. Liu C, Lou W, Zhu Y, Yang JC, Nadiminty N, Gaikwad NW, Evans $\mathrm{CP}$ and Gao AC: Intracrine androgens and AKR1C3 activation confer resistance to enzalutamide in prostate cancer. Cancer Res 75: 1413-1422, 2015.

9. Schrader AJ, Schrader MG and Cronauer MV: Words of wisdom. Re: Androgen receptor splice variants mediate enzalutamide resistance in castration-resistant prostate cancer cell lines. Eur Urol 64: 169-170, 2013.

10. Arora VK, Schenkein E, Murali R, Subudhi SK, Wongvipat J, Balbas MD, Shah N, Cai L, Efstathiou E, Logothetis C, et al: Glucocorticoid receptor confers resistance to anti-androgens by bypassing androgen receptor blockade. Cell 155: 1309-1322, 2013.

11. Joseph JD, Lu N, Qian J, Sensintaffar J, Shao G, Brigham D, Moon M, Maneval EC, Chen I, Darimont B, et al: A clinically relevant androgen receptor mutation confers resistance to second-generation anti-androgens enzalutamide and ARN-509. Cancer Discov 3: 1020-1029, 2013.

12. Korpal M, Korn JM, Gao X, Rakiec DP, Ruddy DA, Doshi S, Yuan J, Kovats SG, Kim S, Cooke VG, et al: An F876L mutation in androgen receptor confers genetic and phenotypic resistance to MDV3100 (enzalutamide). Cancer Discov 3: 1030-1043, 2013.

13. Kawata H, Ishikura N, Watanabe M, Nishimoto A, Tsunenari T and Aoki Y: Prolonged treatment with bicalutamide induces androgen receptor overexpression and androgen hypersensitivity. Prostate 70: 745-754, 2010.

14. Colabufo NA, Pagliarulo V, Berardi F, Contino M, Inglese C, Niso M, Ancona P, Albo G, Pagliarulo A and Perrone R: Bicalutamide failure in prostate cancer treatment: Involvement of Multi Drug Resistance proteins. Eur J Pharmacol 601: 38-42, 2008.

15. Bohl CE, Gao W, Miller DD, Bell CE and Dalton JT: Structural basis for antagonism and resistance of bicalutamide in prostate cancer. Proc Natl Acad Sci USA 102: 6201-6206, 2005.

16. Saad F, Adachi JD, Brown JP, Canning LA, Gelmon KA, Josse RG and Pritchard KI: Cancer treatment-induced bone loss in breast and prostate cancer. J Clin Oncol 26: 5465-5476, 2008.

17. Salturk Z, Çakır O, Kumral TL, Yıldırım G, Ötünçtemur A, Aydoğdu İ and Uyar Y: Subjective and objective effects of androgen ablation therapy on voice. J Voice 29: 490-493, 2015.

18. McCarty MF, Hejazi J and Rastmanesh R: Beyond androgen deprivation: Ancillary integrative strategies for targeting the androgen receptor addiction of prostate cancer. Integr Cancer Ther 13: 386-395, 2014

19. Lamont KR and Tindall DJ: Minireview: Alternative activation pathways for the androgen receptor in prostate cancer. Mol Endocrinol 25: 897-907, 2011.

20. Brooke GN and Bevan CL: The role of androgen receptor mutations in prostate cancer progression. Curr Genomics 10 18-25, 2009.

21. Armstrong $\mathrm{CM}$ and Gao AC: Drug resistance in castration resistant prostate cancer: Resistance mechanisms and emerging treatment strategies. Am J Clin Exp Urol 3: 64-76, 2015.

22. Elbarbry F and Elrody N: Potential health benefits of sulforaphane: A review of the experimental, clinical and epidemiological evidences and underlying mechanisms. J Med Plants Res 5: 473-484, 2011.

23. Zhang Y and Tang L: Discovery and development of sulforaphane as a cancer chemopreventive phytochemical. Acta Pharmacol Sin 28: 1343-1354, 2007.

24. Clarke JD, Dashwood RH and Ho E: Multi-targeted prevention of cancer by sulforaphane. Cancer Lett 269: 291-304, 2008.
25. Cheung KL and Kong AN: Molecular targets of dietary phenethyl isothiocyanate and sulforaphane for cancer chemoprevention. AAPS J 12: 87-97, 2010.

26. Traka MH, Melchini A and Mithen RF: Sulforaphane and prostate cancer interception. Drug Discov Today 19: 1488-1492, 2014.

27. Keum YS, Khor TO, Lin W, Shen G, Kwon KH, Barve A, Li W and Kong AN: Pharmacokinetics and pharmacodynamics of broccoli sprouts on the suppression of prostate cancer in transgenic adenocarcinoma of mouse prostate (TRAMP) mice: Implication of induction of Nrf2, HO-1 and apoptosis and the suppression of Akt-dependent kinase pathway. Pharm Res 26: 2324-2331, 2009

28. Shapiro TA, Fahey JW, Dinkova-Kostova AT, Holtzclaw WD, Stephenson KK, Wade KL, Ye L and Talalay P: Safety, tolerance, and metabolism of broccoli sprout glucosinolates and isothiocyanates: a clinical phase I study. Nutr Cancer 55: 53-62, 2006.

29. Petri N, Tannergren C, Holst B, Mellon FA, Bao Y, Plumb GW, Bacon J, O'Leary KA, Kroon PA, Knutson L, et al: Absorption/ metabolism of sulforaphane and quercetin, and regulation of phase II enzymes, in human jejunum in vivo. Drug Metab Dispos 31: 805-813, 2003.

30. Singh SV, Srivastava SK, Choi S, Lew KL, Antosiewicz J, Xiao D, Zeng Y, Watkins SC, Johnson CS, Trump DL, et al: Sulforaphane-induced cell death in human prostate cancer cells is initiated by reactive oxygen species. J Biol Chem 280: 19911-19924, 2005.

31. Xiao D, Powolny AA, Antosiewicz J, Hahm ER, Bommareddy A, Zeng Y, Desai D, Amin S, Herman-Antosiewicz A and Singh SV: Cellular responses to cancer chemopreventive agent $\mathrm{D}, \mathrm{L}$-sulforaphane in human prostate cancer cells are initiated by mitochondrial reactive oxygen species. Pharm Res 26: 1729-1738, 2009.

32. Pei Y, Wu B, Cao Q, Wu L and Yang G: Hydrogen sulfide mediates the anti-survival effect of sulforaphane on human prostate cancer cells. Toxicol Appl Pharmacol 257: 420-428, 2011.

33. Zhang C, Su ZY, Khor TO, Shu L and Kong AN: Sulforaphane enhances Nrf2 expression in prostate cancer TRAMP C1 cells through epigenetic regulation. Biochem Pharmacol 85: 1398-1404, 2013.

34. Schultz MA, Hagan SS, Datta A, Zhang Y, Freeman ML, Sikka SC, Abdel-Mageed AB and Mondal D: Nrf1 and Nrf2 transcription factors regulate androgen receptor transactivation in prostate cancer cells. PLoS One 9: e87204, 2014.

35. Kensler TW, Egner PA, Agyeman AS, Visvanathan K, Groopman JD, Chen JG, Chen TY, Fahey JW and Talalay P: Keap1-nrf2 signaling: A target for cancer prevention by sulforaphane. Top Curr Chem 329: 163-177, 2013.

36. Kim SH and Singh SV: D,L-Sulforaphane causes transcriptional repression of androgen receptor in human prostate cancer cells. Mol Cancer Ther 8: 1946-1954, 2009.

37. Wiczk A, Hofman D, Konopa G and Herman-Antosiewicz A: Sulforaphane, a cruciferous vegetable-derived isothiocyanate, inhibits protein synthesis in human prostate cancer cells. Biochim Biophys Acta 1823: 1295-1305, 2012.

38. Gibbs A, Schwartzman J, Deng V and Alumkal J: Sulforaphane destabilizes the androgen receptor in prostate cancer cells by inactivating histone deacetylase 6. Proc Natl Acad Sci USA 106: 16663-16668, 2009.

39. Wu HC, Hsieh JT, Gleave ME, Brown NM, Pathak S and Chung LW: Derivation of androgen-independent human LNCaP prostatic cancer cell sublines: Role of bone stromal cells. Int J Cancer 57: 406-412, 1994.

40. Uygur B and Wu WS: SLUG promotes prostate cancer cell migration and invasion via CXCR4/CXCL12 axis. Mol Cancer 10: 139, 2011.

41. Chou TC: Drug combination studies and their synergy quantification using the Chou-Talalay method. Cancer Res 70: 440-446, 2010.

42. Horoszewicz JS, Leong SS, Chu TM, Wajsman ZL, Friedman M, Papsidero L, Kim U, Chai LS, Kakati S, Arya SK, et al: The LNCaP cell line - a new model for studies on human prostatic carcinoma. Prog Clin Biol Res 37: 115-132, 1980.

43. Cunningham D and You Z: In vitro and in vivo model systems used in prostate cancer research. J Biol Methods 2: pii: e17, 2015.

44. Agoulnik IU, Vaid A, Bingman WE, Erdeme H, Frolov A, Smith CL, Ayala G, Ittmann MM and Weigel NL: Role of SRC-1 in the promotion of prostate cancer cell growth and tumor progression. Cancer Res 65: 7959-7967, 2005. 
45. He S, Zhang C, Shafi AA, Sequeira M, Acquaviva J, Friedland JC, Sang J, Smith DL, Weigel NL, Wada Y, et al: Potent activity of the Hsp90 inhibitor ganetespib in prostate cancer cells irrespective of androgen receptor status or variant receptor expression. Int J Oncol 42: 35-43, 2013.

46. Ai J, Wang Y, Dar JA, Liu J, Liu L, Nelson JB and Wang Z: HDAC6 regulates androgen receptor hypersensitivity and nuclear localization via modulating Hsp90 acetylation in castrationresistant prostate cancer. Mol Endocrinol 23: 1963-1972, 2009.

47. Myzak MC, Tong P, Dashwood WM, Dashwood RH and Ho E: Sulforaphane retards the growth of human PC-3 xenografts and inhibits HDAC activity in human subjects. Exp Biol Med (Maywood) 232: 227-234, 2007.

48. Shiota M, Yokomizo A and Naito S: Oxidative stress and androgen receptor signaling in the development and progression of castration-resistant prostate cancer. Free Radic Biol Med 51: $1320-1328,2011$

49. Demir A, Cecen K, Karadag MA, Kocaaslan R and Turkeri L: The course of metastatic prostate cancer under treatment. Springerplus 3: 725, 2014.

50. Lee JG, Zheng R, McCafferty-Cepero JM, Burnstein KL, Nanus DM and Shen R: Endothelin-1 enhances the expression of the androgen receptor via activation of the c-myc pathway in prostate cancer cells. Mol Carcinog 48: 141-149, 2009.

51. Mostaghel EA and Nelson PS: Intracrine androgen metabolism in prostate cancer progression: Mechanisms of castration resistance and therapeutic implications. Best Pract Res Clin Endocrinol Metab 22: 243-258, 2008.
52. Mostaghel EA, Page ST, Lin DW, Fazli L, Coleman IM, True LD, Knudsen B, Hess DL, Nelson CC, Matsumoto AM, et al: Intraprostatic androgens and androgen-regulated gene expression persist after testosterone suppression: Therapeutic implications for castration-resistant prostate cancer. Cancer Res 67: 5033-5041, 2007.

53. Huo C, Kao $\mathrm{YH}$ and Chuu CP: Androgen receptor inhibits epithelial-mesenchymal transition, migration, and invasion of PC-3 prostate cancer cells. Cancer Lett 369: 103-111, 2015.

54. Singh SV, Warin R, Xiao D, Powolny AA, Stan SD, Arlotti JA, Zeng Y, Hahm ER, Marynowski SW, Bommareddy A, et al: Sulforaphane inhibits prostate carcinogenesis and pulmonary metastasis in TRAMP mice in association with increased cytotoxicity of natural killer cells. Cancer Res 69: 2117-2125, 2009.

55. Aapro MS, Eliason JF, Krauer F and Alberto P: Colony formation in vitro as a prognostic indicator for primary breast cancer. J Clin Oncol 5: 890-896, 1987.

56. Kallifatidis G1, Rausch V, Baumann B, Apel A, Beckermann BM, Groth A, Mattern J, Li Z, Kolb A, Moldenhauer G, et al: Sulforaphane targets pancreatic tumour-initiating cells by $\mathrm{NF}-\kappa \mathrm{B}-$-induced antiapoptotic signaling. Gut 58: 949-963, 2009. 